\title{
The Effect of Classroom Debate Activities on Pre-service Teachers' Argumentativeness
}

\author{
Kübra Şengül \& Ahmet Demirel \\ Nevsehir Haci Bektas Veli University, Nevsehir, TURKEY \\ Education Faculty
}

Received: 29 April 2021 - Accepted: 21 June 2021 • Published Online: 22 August 2021

\begin{abstract}
The aim of this study is to examine the effect of classroom debate activities on the argumentativeness of Turkish language teacher candidates. The study group of the research consists of 29 freshman students in the Turkish Language Teaching program. Designed in mixed method, in this study Argumentativeness Scale and Semi-Structured Interview Form were used as data collection tools. The application process of the study took a total five weeks. For the analysis of the quantitative data which was obtained through the Argumentativeness Scale, the pre and post-test scores were compared using the t-test. However, at the end of the application, the opinions of the students were taken through the semi-structured interview form and these data were analyzed using the content analysis technique. As a result of the research, it was determined that there is a significant difference between the argumentativeness pre-test scores and post-test scores of the study group. The findings obtained from the interviews also confirmed that there is a difference in the argumentativeness of the teacher candidates. As a result, it was seen that classroom debate activities carried out in accordance with the rules can motivate prospective teachers to do discussions and reduce their anxiety and fear of discussions. In addition to this, according to the findings, debate activities encourage students to do research, create a competitive environment in the classroom and ensure active participation in the lessons. In line with the research results, suggestions for classroom discussion practices and suggestions for future research have been presented.
\end{abstract}

Keywords: debate activities, argumentativeness, discussion skills.

\section{Introduction}

Discussion involves the processes of dealing with an issue, expressing it with its positive and negative aspects, and presenting it with support and evidence (Kinneavy, 1971). Kuhn (1991) considered discussion as a necessary skill for generating ideas and problem solving. Turunç, Eser and Dinç (2018) emphasize that debate is of vital importance for the development of thought. Discussions can enable people to apply different mental processes, compare their thoughts with those of others', and learn the functioning of thinking processes (Güneş, 2012). Vázquez (2002) stated that the discussion is the result of mental reasoning whether in written or verbal format. Brookfield and Preskill (2005) emphasized that discussion is a way of teaching and is important for creating a democratic classroom environment. Discussion is an important process for generating ideas and solving problems in these aspects.

(C) Authors. Terms and conditions of Creative Commons Attribution 4.0 International (CC BY 4.0) apply. Correspondence: Kübra Şengül, Nevsehir Haci Bektas Veli University, Education Faculty, Nevsehir, TURKEY. E-mail: kubraturkersengul@gmail.com. 
Involving students in discussions deliberately has been accepted as a teaching method that serves various purposes from elementary school to higher education by educators (Brookfield \& Preskill, 2005; Kuhn, Wang \& Li, 2010). Gall and Gillett (1980) state that the discussion is a technique used by teachers for many different purposes such as helping students understand the subject better, improving their problem-solving skills, and teaching them to respect others. Discussion is one of the techniques recommended by educators for improving thinking skills. In curriculums, it is projected that the students share their opinions and thoughts, and learn new ideas by discussing them (Güneş, 2012). Gall and Gillett (1980) stated that discussion is a method that not only supports teacher-student interaction, but it also triggers students to learn from each other in the classroom, so teachers and students should be trained to use discussion skills. Discussion is an essential technique for mental development and interaction between the students and teachers. Discussions practiced in accordance with rules also mediate the parties to learn from each other.

Discussions conducted in accordance with rules in the classroom can encourage students' participation in the lesson. Since discussion is a reciprocal action, it is an effective method to ensure students' active participation. As a matter of fact, Tokdemir (2013) found in his study that the discussion method promotes students' participation skills and encourages them to do research. In addition, discussions practiced in accordance with rules will support speaking and writing skills. Although discussion is an activity that can be performed verbally or in writing, it is usually carried out through verbal speaking and listening skills. Discussion method, in which speaking and listening skills are actively used, contributes to speaking and listening skills in that sense. It promotes attentive and respectful listening. Dallimore, Hertenstein and Platt (2008) emphasized that discussion is a very useful method that can be used to improve oral and written communication skills. Tokdemir (2013) stated that the discussion method supports the communication and interpretation skills of the students.

Classroom discussions can provide interest and motivation regarding the topic. Discussion can be carried out individually or as a group. By any means, the person has views that the s/he defends or will defend individually or as a group. This situation allows the debater to do more research on the subject and be more interested in the subject. Hence, Huerta (2007) stated that discussion supports active participation. Besides, discussions in classroom environment provide an opportunity to look at the subject from different perspectives. There is always room for different opinions and ideas in a discussion. Pollock, Hamann and Wilson (2011) stated that in the literature, discussion is emphasized as a method that can be used to develop students' critical thinking skills.

With that being said, discussion is a method that can contribute to educational environments in many aspects such as encouraging coming to the lessons prepared, developing cooperative learning, promoting research, and teaching to listen on the basis of respect. Developing the teacher candidates' communication and discussion skills and so that they can use this in the classroom will increase the effectiveness of the education. For this reason, effective communication should be established in educational settings and discussion method should be used within the limitations (Ocak, Karakuş \& Ocak, 2018). In their research, Ocak, Karakuş and Ocak (2018) examined the relationship between the communication skills and discussion skills of prospective teachers and concluded that there is a positive significant relationship between communication skills and discussion skills, and communication skills are an important predictor of discussion skills. From this aspect, it can be said that discussion, which is a communication type, is a method that can be used to strengthen students' communication skills.

In discussions, methods such as small group discussions, large group discussions, forums, seminars, six thinking hats, six action shoes, circle technique, opposite panel, panel discussions, debates etc. can be used (Demir, Şahin \& Tutkun, 2016). Debate is one of the methods that can be used to discuss in lessons and to improve democracy in the classroom (Demir, Şahin 
\& Tutkun, 2016). Debate technique emerges as one of the techniques frequently used in discussions. Although there are many different ways of practice, debates are generally a discussion technique in which two groups who advocate opposing opinions on a topic defend their opinions in front of a jury within the framework of certain rules.

Debates attract students' attention because of they are of a competitive nature. In addition to this, it is a useful technique in terms of improving students' oratory skills, boosting their self-confidence, and seeing the different aspects of a subject. During debates, students can also defend opinions that they do not agree with or that they do not believe to be correct (Tokdemir, 2013). During discussions in the form of debates, students take sides on the relevant issue. They identify and discuss their views around the question. In this aspect, the aim is not to reach the truth but to win the discussion. For this purpose, while the students strengthen their own views, they make an effort to find the weaknesses of the other side (Kuhn, 1991).

Discussion, a democratic activity, is peculiar to people. Schools are responsible for providing students with democratic discussion attitudes and behaviors. Learning and developing to think without thinking, and to criticize without criticizing is not just difficult but impossible. An effective way to overcome this impossibility is the use of discussions in educational activities. Individuals should be allowed to learn to discuss by doing, experiencing, and observing (Yeşil, 2004). The argumentativeness of people has a very important place for the materialization of quality discussion activities both in the classroom and in all social settings. Thus, the attitudes of the people taking part in discussions are an important factor in the initiation and continuation of the discussions with due regard.

Argumentativeness refers to the characteristic of the individual in the communication process that represents the individual's tendency to defend his/her position and verbally attack the position of the other party regarding controversial issues (Infante \& Rancer, 1982). It is suggested that individuals with strong argumentativeness have lower motivation to avoid discussions and have higher tendencies to argue (as cited in Turunç, Eser \& Dinç, 2018). While the individual with higher argumentativeness trusts his/her ability to discuss to a great extent, the one with low trust cannot depend on this ability much (Infante \& Rancer, 1982). Infante, Trebing, Shepherd and Seeds (1984) emphasized that there is a relationship between argumentativeness and verbal aggression by stating that verbal aggression can mainly result from a lack of discussion skills. Therefore, it is important to develop the argumentativeness of the students and help them develop a discussion culture.

The general purpose of this study is to reveal the effect of the debates held in the classroom environment on the argumentativeness of Turkish teacher candidates. In line with this general purpose, answers to the following questions are looked for:

1. Is there a significant difference between the pre-test and post-test scores that the pre-service teachers got from the overall argumentativeness scale?

1.1. Is there a significant difference between the pre-test and post-test scores of the pre-service teachers' argumentativeness in terms of approach dimension, which is a sub-dimension of the argumentativeness scale?

1.2. Is there a significant difference between the pre-test and post-test scores of the pre-service teachers' argumentativeness in terms of avoidance dimension, which is a sub-dimension of the argumentativeness scale?

2. What are the opinions of the teacher candidates on the effects of debates on their own argumentativeness? 


\section{Method}

This research was designed in a mixed method in which qualitative and quantitative approaches are both used. The mixed method research enables the use of qualitative and quantitative approaches together (Creswell \& Clark, 2018). The mixed method is preferred here because the aim is to reach detailed and reliable results using both qualitative and quantitative data in the study.

First of all, quantitative data was collected in the research. Then, it was attempted to explain the quantitative data using the qualitative data. For this reason, sequential descriptive design was used which can be used in mixed method research. In sequential descriptive design, quantitative data is reviewed first. After the quantitative data, usually the qualitative data is used to explain and expand on the quantitative data. The analysis of the quantitative and qualitative data collected is interpreted in relation to each other and for this reason; these data sets are combined in the commentary and discussion sections (Creswell \& Clark, 2018).

\subsection{Study group}

29 students that were registered at a state university in Turkey during the fall semester of 2019-2020 academic year constitute the study group of this research. There is only one group since the quantitative aspect of the research is designed in a single group pre-test/post-test quasiexperimental design. Convenience sampling method was used to determine the study group in the study. In the convenience sampling method, the study group is selected based on its proximity to the researcher and convenience of accessibility (Creswell \& Clark, 2018).

\subsection{Data collection tools}

The Argumentativeness Scale: Originally developed by Infante and Rancer (1982), the validation study of the Argumentativeness Scale's Turkish version was carried out by Turunç, Eser and Dinç (2018). Within this scope, the scale was translated into Turkish using the translation and back-translation method, and it was applied to a total of 1561 university students, 997 of which were females and 564 were males. The scale was tested by making comparisons with exploratory and confirmatory factor analyses and internal consistency analysis applied at different times in two separate samples. As a result of the exploratory factor analysis, two dimensions (Tendency to Avoid Arguments and Tendency to Approach Arguments) of the Abbreviated Argumentativeness Scale compatible with the original were confirmed in both female and male student samples. As a result of the analyses carried out, it was determined that the abbreviated 10item form of the argumentativeness scale is a reliable and valid measurement tool, and it consists of two sub-dimensions as approach and avoidance. In addition, Cronbach Alpha, which indicates the internal consistency of this scale, was calculated as .71 (Turunç, Eser \& Dinç, 2018). The Cronbach Alpha Coefficient of the scale obtained in this study was determined as .70.

Semi-Structured Interview Form: The semi-structured interview form that has been developed aims to reveal the effect of classroom debates on pre-service teachers' argumentativeness. This interview form, which was prepared by the researcher(s) in order to reveal the effects of classroom discussions on students' argumentativeness, was finalized after receiving opinions from two field experts. There are a total of two open-ended questions in the semi-structured interview form. 


\subsection{Data collection procedure}

In the data collection process of the study, the Argumentativeness Scale, which was developed by Infante and Rancer (1982), and validity and reliability study of which was conducted by Turunç, Eser and Dinç (2018) were applied to the study group as a pre-test before the in-class discussion practices were initiated during the data collection process. After the pre-test application, debates were held with the students within the framework of the curriculum, one day a week, for a total of 5 weeks. It was ensured that each student took part in at least one debate activity for 5 weeks. At the end of the 5 -week process, the argumentativeness scale was applied to the students as a post-test, and then their views on the effects of the debates on their argumentativeness were taken through the semi-structured interview form developed by the researcher. These interviews were recorded using a voice recorder. The research was conducted as part of Turkish Language 1 course in the fall semester of the 2019-2020 academic year.

\subsection{Experimental process}

1 below.

The steps of the experimental process conducted in four stages are presented in Figure

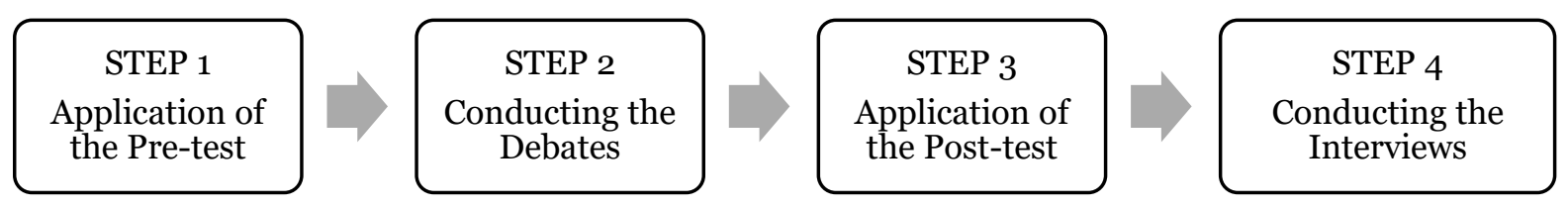

Figure 1. Schematic representation of the experimental process

In the first stage of the experimental, a pre-test was applied to the study group. Students were asked to answer the Argumentativeness Scale in a way reflecting the reality. The data obtained from the Students' Argumentativeness Scale was processed as pre-test scores.

In the second phase, debates were held with the students for 2 hours a week for 5 weeks. At the beginning of the debates and throughout the process, students were often reminded of the rules to be followed in the discussions. It was made sure that each student was included in at least one debate group. A debate was held each week, with two groups supporting one opinion each and two opposing groups debating each other. However, a fixed jury was determined and after the debates, the jury made their evaluations. The first stage of the debates was group discussions, and the last stage was the question-answer stage.

In the third step, the post-test application was carried out with the study group. In the post-test, the data was obtained by using the Argumentativeness Scale as in the pre-test. The data obtained from the scale was processed as the post-test.

In the fourth step, the interview technique was used by utilizing the semi-structured interview form developed by the researcher in order to obtain the qualitative data of the study. The interviews were recorded on a voice recorder and transferred to written media. The data transferred to the written media was analyzed using the content analysis technique.

The research lasted for a total of eight weeks, including one week of pre-tests, five weeks of classroom debate activities, and two weeks of post-tests and interviews. 


\subsection{Data analysis}

For the analysis of quantitative data, numerical data obtained through the Argumentativeness Scale was used. It was checked whether there was a significant difference between the group's pre-test and post-test argumentativeness scores. In order to determine whether pre-test and post-test scores of pre-service teachers differ in general and according to the sub-dimensions of the scale, dependent samples t-test was applied. In the analysis of qualitative data, the data obtained through a semi-structured interview form and the data recorded with the help of a voice recording device which was transferred to written media were analyzed using the content analysis technique. A qualitative research program was utilized for the content analysis.

\section{Results}

This section includes the findings obtained in accordance with the aims of the research.

\subsection{Findings regarding the quantitative dimension of the study}

Whether the data obtained in the study showed normal distribution was analyzed using the Shapiro-Wilk test. The findings are presented in Table 1.

Table 1. Argumentativeness scale Shapiro-Wilk test results

\begin{tabular}{llccc}
\hline & & Statistics & SD & p \\
\hline \multirow{2}{*}{$\begin{array}{l}\text { Argumentativeness } \\
\text { Scale }\end{array}$} & Pre-test & .932 & 29 & .063 \\
\cline { 2 - 5 } & Post-test & .969 & 29 & .533 \\
\hline
\end{tabular}

When Table 1 is examined, it is seen that each data set has a normal distribution ( $p=>.05)$. The normal distribution of the pre-test and post-test data sets means that parametric tests (t-tests) can be applied to the data. For this reason, in the study, whether there is a significant difference between the students' argumentativeness scale pre-test and post-test mean scores was examined using the dependent sample t-test and the results were given in tables.

Table 2. Paired sample t-test results of tendency to avoid arguments dimension pre and post-test average scores

\begin{tabular}{llllllll}
\hline & & N & Mean & S & SD & t & p \\
\hline $\begin{array}{l}\text { Tendency to Avoid } \\
\text { Arguments }\end{array}$ & Pre-test & 29 & 2.91 & .67 & & & \\
\cline { 2 - 5 } & $\begin{array}{l}\text { Post- } \\
\text { test }\end{array}$ & 29 & 2.36 & .42 & 28 & 2.83 & .001 \\
\hline
\end{tabular}

Upon examining Table 2, it is seen that there is a negative significant difference between the tendency to avoid arguments dimension pre-test and post-test scores, which form a sub-dimension of the pre-service teachers' argumentativeness scale $\left(\mathrm{t}_{28}=2.83 ; \mathrm{p}=.001<.05\right)$. This shows that classroom debating activities contributed to the decrease in pre-service teachers' tendency to avoid arguments.

Tendency to approach arguments is another dimension of the Argumentativeness Scale. The results of the t-test for tendency to approach arguments dimension are presented in Table 3:

Table 3. Dependent sample t-test results of tendency to approach arguments dimension pre and post-test average scores

\begin{tabular}{llllllll}
\hline & & $\mathbf{N}$ & Mean & S & SD & t & p \\
\hline \multirow{2}{*}{$\begin{array}{l}\text { Tendency to } \\
\text { Approach Arguments }\end{array}$} & Pre-test & 29 & 3.40 & .82 & & & \\
\cline { 2 - 5 } & $\begin{array}{l}\text { Post- } \\
\text { test }\end{array}$ & 29 & 3.77 & .64 & 28 & -2.27 & .031 \\
\hline
\end{tabular}


Upon examining Table 3 , it is seen that there is a positive significant difference between the tendency to approach arguments dimension pre-test and post-test scores, which form a dimension of the pre-service teachers' argumentativeness scale $\left(t_{28}=-2.27 ; p=.031<.05\right)$. This shows that classroom debate activities are effective in encouraging prospective teachers to do argument.

\subsection{Findings regarding the qualitative dimension of the study}

In this aspect of the research, the findings and results obtained from the interviews with 8 of the students participating in the research are included. The data obtained in the qualitative aspect of the research was analyzed using the content analysis technique. The following figure was created in accordance with the data obtained:

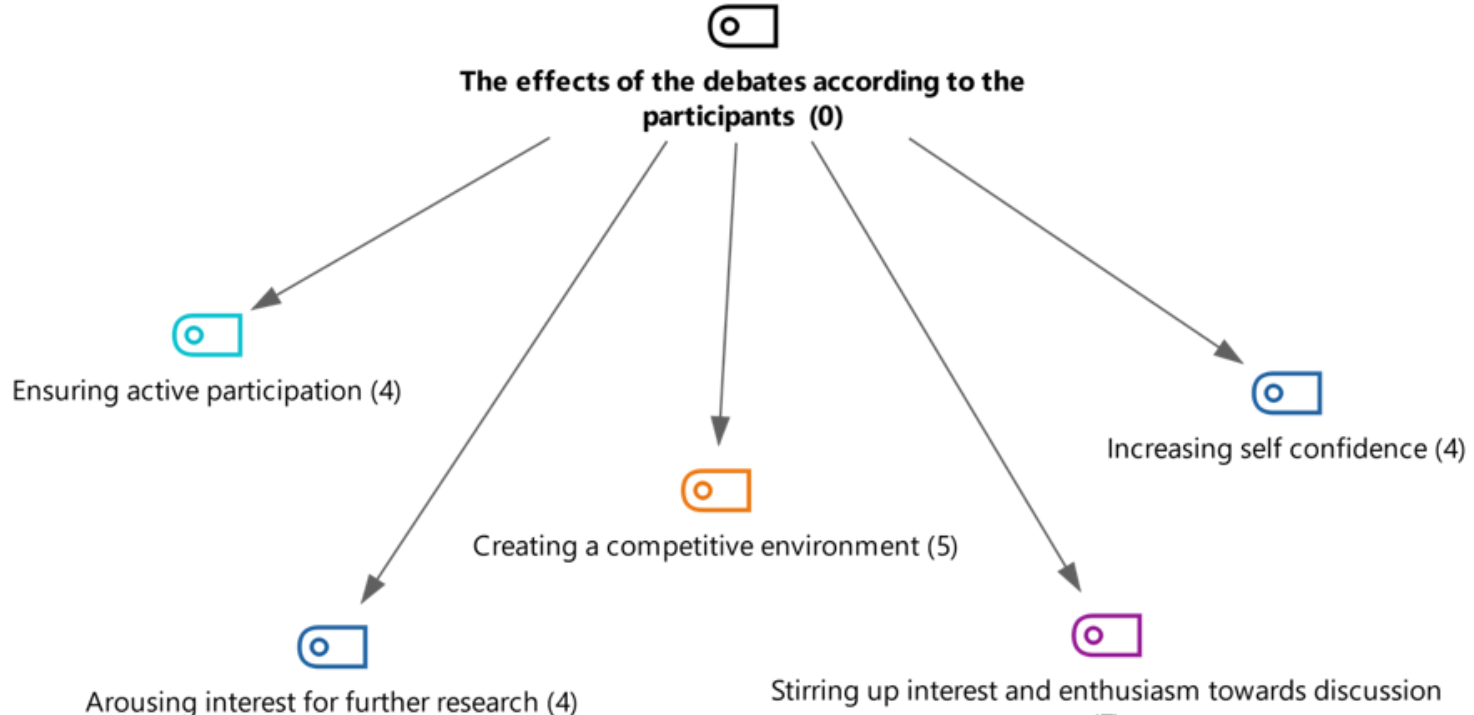

Arousing interest for further research (4)

(7)

Figure 2. The effect of the debate activities according to the participant

Some of the opinions of the participants who stated that the debates encourage them to discuss and do research, increase their self-confidence, create a competitive environment, and enable them to participate actively in the class are as follows:

"Before the debates were held, since the topics of discussion were known, we did some reading and research with our friends. The debate events created a nice environment for us to express our thoughts. Thanks to these events, we expressed our thoughts easily." (Participant 1)

"As I attended the debates, I realized that there was nothing to be afraid of. This situation encouraged me." (Participant 4)

"The debates helped us learn about the subjects. That was because we had to gather information on the subject before the debates were held. Therefore, this situation enabled us to be knowledgeable about the subject. I think that as our knowledge on the subject increases, our willingness to participate in discussions also increases." (Participant 5)

"With the help of these debates, I learned how to do research while getting ready to debate, the points that I should pay attention to while defending my views, how to be respectful to the other party's views, and how to express myself. Therefore, these debates showed me very clearly that I should not avoid discussions and should not hesitate to express my views." (Participant 6) 
"All of our friends have attended the debates that we have organized. At this point, I think debates encourage active participation. There was a fun atmosphere in the classroom. I can say that the more I see my friends participate in the discussions, the more I will be willing to discuss." (Participant 7)

"These debates we have organized had a positive effect on my argumentativeness. Before these debates, I would hesitate to discuss, to be involved in any discussion, and try to stay away as much as possible, but now I do not hesitate and say that if I think an idea is really true, I will defend and support it till the end." (Participant 8)

\section{Discussion}

According to the findings of the research, debate activities organized in the classroom in accordance with rules encourage students to do research, participate in the lesson and discuss. Therefore, classroom debate activities organized within a framework of the rules and purposes can be useful in encouraging students who avoid discussion. Göçmez (2016) stated that discussion methods, especially debate technique, are used very little in education. It will especially be beneficial to use the discussion methods, specifically the debate technique, effectively in classroom settings. As a matter of fact, Göçmez (2016) stated in his study that the group that had their lessons using the debate technique showed a positive improvement in terms of course success and critical thinking skills compared to the group that had their lessons using traditional methods. The findings of this study also showed that debate activities can encourage students to discuss, thus encouraging active participation. Considering the importance of active participation in education, the significance of discussion techniques with the participation of students can be understood better.

In his study, Sarıgöz (2013) stated that the discussion method is a method that can improve students' listening, generating ideas, questioning, and evaluation skills. Findings obtained in this study also showed that debate activities can be useful for students to develop selfconfidence, create a competitive environment, and actively participate in the lesson. Infante and Rancer (1982) stated that an individual who develops an argument will experience a sense of accomplishment. In this study, it was seen that discussions in which arguments are put forward can increase students' self-confidence. The findings of this study also showed that the debating technique can be effective in developing students' argumentativeness. In addition to all these, the findings of the study conducted by Cin Şeker (2020) showed that Turkish teachers' attitudes towards discussion skills differ according to the number of books read. According to the findings of this study, Turkish teacher candidates who read 5-6 or more books a month have more positive attitudes towards their discussion skills.

According to the results of the research, debates for which students get to prepare beforehand encourage students to do research on the subject. This situation contributes to the students' ability to express their opinions on the subject and to participate in the discussions. This result of the research matches up with the study carried out by Tokdemir (2013). As a matter of fact, Tokdemir also reached the conclusion in his research that the discussion method motivates students to do research. However, Göçmez (2016) stated that the debates encourage students to do research and that the topics of the debate should be announced to them at least two weeks in advance in order for them to be able to do research. The findings obtained in this study also support the opinions expressed by Göçmez (2016) and Tokdemir (2013). Therefore, it can be said that one of the techniques that can be used in education to encourage students to do research on a subject is debate. However, before the debates are held, the topics for the debate and the dates for the debates should be determined in advance so that the students can do enough research on the subject. 


\section{Conclusions}

According to the results of the research, debates create a competitive and challenging environment in the classroom which encourages students to participate in the discussions. After participating in discussions several times, the fear and anxiety felt by the students about participating in discussions decreases. Debates organized for the active participation of students can prevent their fear and anxiety towards participating in discussions as they positively affect each other. As a matter of fact, the students stated that their anxiety and fear diminished as they witnessed the discussions done by their friends during their interviews. For this reason, doing discussion practices frequently in educational environments will help prevent students' anxiety towards discussions.

The findings of the research showed that discussion technique, in general, and debate technique, in particular, can be used in order to ensure active participation in the lesson in educational environments, so that the students develop discussion attitudes and gain a culture of discussion. However, when discussion techniques are used, it will be beneficial to provide students with training on this subject. Otherwise, unwanted situations may happen during discussions. The findings of the research show that the argumentativeness can be improved. For this reason, it is important to investigate what other practices can be used to develop discussion attitudes in educational environments, and to create democratic classroom environments.

\section{Acknowledgements}

This research did not receive any specific grant from funding agencies in the public commercial, or not-for-profit sectors.

The authors declare no competing interests.

\section{References}

Brookfield, S. D., \& Preskill, S. (2005). Discussion as a way of teaching: Tools and techniques for democratic classrooms ( $2^{\text {nd }}$ edition). New York: Wiley.

Büyüköztürk, Ş., Kılıç Çakmak, E., Akgün, Ö. E., Karadeniz, Ş., \& Demirel, F. (2016). Bilimsel araştırma yöntemleri [Scientific research methods]. Ankara: Pegem Akademi.

Cin Şeker, Z. (2020). Attitudes of Turkish teacher candidates towards discussion. Journal of Language and Linguistic Studies, 16(2), 993-1005. https://doi.org/10.17263/jlls.759355

Creswell, J. W., \& Clark, V. L. P. (2018). Karma yöntem araştırmaları tasarımı ve yürütülmesi [Designing and conducting mixed methods research]. (Çev. Ed. Dede, Y. \& Demir SB) Ankara: Anı Yayıncilik.

Dallimore, E. J., Hertenstein, J. H., \& Platt, M. B. (2008). Using discussion pedagogy to enhance oral and written communication skills. College Teaching, 56(3), 163-172. https://doi.org/10.3200/CTCH.56.3.163-172

Demir, M. K., Şahin, Ç., \& Tutkun, T. (2016). Sosyal bilgiler dersi için sınıf öğretmeni adaylarının münazara konusu oluşturma becerilerinin değerlendirilmesi [Ánalyzing candidate classroom teachers' skill of identifying a subject of debate in social studies course]. Atatürk Üniversitesi Kazım Karabekir Ë̆itim Fakültesi Dergisi, (32), 51-66. Retrieved from https://dergipark.org.tr/en/pub/ataunikkefd/issue/26879/282678. 
K. Şengül \& A. Demirel - The Effect of Classroom Debate Activities on Pre-service...

Gall, M. D., \& Gillett, M. (1980). The discussion method in classroom teaching. Theory Into Practice, 19(2), 98-103. https://doi.org/10.1080/0040584800954288

Göçmez, B. (2016). İlkokul 4. sınıf sosyal bilgiler dersinde münazara tekniğinin ders başarısı ve eleştirel düşünmeye etkisi [The effect of the debate technique in the primary school 4th-grade social sciences course on the coursesuccess and critical thinking]. Unpublished Master's Thesis, Çanakkale Onsekiz Mart Üniversitesi, Eğitim Bilimleri Enstitüsü, Çanakkale.

Güneş, F. (2012). Öğrencilerin düşünme becerilerini geliştirme [Improving the thinking skills of students]. Türklük Bilimi Araştırmaları, (32), 127-146. Retrieved from https://dergipark.org.tr/en/download/article-file/157123.

Hamilton, M. A., \& Mineo, P. J. (2002). Argumentativeness and its effect on verbal aggressiveness: A metaanalytic review. In M. Allen, R. W. Preiss, B. M. Gayle \& N. Burrell (Eds), Interpersonal communication research: Advances through metaanalysis (pp. 281-314). Mahwah, NJ: Lawrence Erlbaum.

Huerta, J. C. (2007). Getting active in the large lecture. Journal of Political Science Education, 3(3), 237249. https://doi.org/10.1080/15512160701558224

Infante, D. A., \& Rancer, A. S. (1982). A conceptualization and measure of argumentativeness. Journal of Personality Assessment, 46(1), 72-80. https://doi.org/10.1207/s15327752jpa4601 13

Infante, D. A., Trebing, J. D., Shepherd, P. E., \& Seeds, D. E. (1984). The relationship of argumentativeness to verbal aggression. Southern Speech Communication Journal,50(1), 67-77. https://doi.org/10.1080/10417948409372622

Kinneavy, J. A. (1971). A theory of discourse: The aims of discourse. Englewood Cliffs, NJ: Prentice Hall.

Kuhn, D. (1991). The skills of argument. Cambridge, UK: Cambridge University Press.

Kuhn, D., Wang, Y., \& Li, H. (2010). Why argue? Developing understanding of the purposes and values of argumentive discourse. Discourse processes, 48(1), 26-49. https://doi.org/10.1080/01638531003653344

Ocak, G., \& Karakuş, G. (2015). Öğretmen adaylarının tartışma becerilerine yönelik tutumları [Pre-service teachers' attitudes towards the ability of discussion]. Trakya University Journal of Social Science, 17(2), 153-170. Retrieved from https://dergipark.org.tr/en/download/articlefile/321304.

Ocak, G., Karakuş, G., \& Ocak, İ. (2018). Öğretmen adaylarının tartışma becerileri ile iletişim becerileri arasındaki ilişkinin incelenmesi [Investigating the relationship between disscussion and communication skills of pre-service teachers]. Trakya University Journal of Social Science, 2O(1). https://doi.org/10.26468/trakyasobed.437704

Pollock, P. H., Hamann, K., \& Wilson, B. M. (2011). Learning through discussions: Comparing the benefits of small-group and large-class settings. Journal of Political Science Education, 7(1), 48-64. https://doi.org/10.1080/15512169.2011.539913

Sarıgöz, O. (2013). Sinıfla ve grupla tartışma yöntemlerinin meslek yüksekokulu öğrencilerinin akademik başarılarına etkisi [Class and group discussion methods effect of higher vocational school students' academic achievement]. Electronic Journal of Vocational Colleges, 3, 100-106. Retrieved from https://dergipark.org.tr/en/download/article-file/62560.

Tokdemir, M. A. (2013). Ortaöğretim tarih dersinin öğretiminde tartışma yöntemine ilişkin öğretmenlerin görüş ve uygulamalar [Teachers' opinions and applications for the use of discussion method in secondary history courses: Sample of Ankara]. Unpublished Dissertation, Gazi Üniversitesi Eğitim Bilimleri Enstitüsü, Ankara

Turunç, Ö., Eser, H. B., \& Dinç, M. (2018). Tartışmacı tutum ölçeği kısa formunun Türkçe geçerlilik ve güvenilirlik analizi [The analysis of Turkish validity and reliability on the short version of argumentativeness scale]. OPUS-Uluslararası Toplum Araştırmaları Dergisi, 9(16), 731-759. https://doi.org/10.26466/opus.480175 
Vázquez, S. M. (2002). Argumentative text: An instructional proposal. Thinking: The Journal of Philosophy for Children, 16(1), 18-22. https://doi.org/10.5840/thinking20021614

Yeşil, R. (2004). Öğrenci ve öğretim elemanlarının tartışma tutum ve davranışları arasındaki ilişki [The relation between the discussion attitudes and behaviors of instructors and students]. Gazi Üniversitesi Krrşehir Eğitim Fakültesi, 5(2), 195-208. Retrieved from https://dergipark.org.tr/en/download/article-file/1336988. 
K. Şengül \& A. Demirel - The Effect of Classroom Debate Activities on Pre-service...

C O A $\mathrm{s}$ 